\title{
Retlige, retssikkerhedsmæssige og resocialiserende omkostninger ved sagsomkostninger i straffesager
}

\author{
Af Annette Olesen ${ }^{1}$
}

\begin{abstract}
According to the Danish Administration of Justice Act, the state has a right of recourse against criminal offenders to recover legal costs (costs of defence lawyers, DNA-tests, technical and accounting investigations, etc.). Denmark is the only Scandinavian country, and most likely the only country in the European Union, that fails to consider a convict's income level when calculating the legal costs to be applied. Nor does Denmark have a common practice of remitting convicts' considerable legal costs. This article focuses on concerns where legal principles, rule of law and reintegration of ex-prisoners are negatively affected by the legislation concerning legal costs.
\end{abstract}

\section{Indledning}

"At de gældende bestemmelser er stærkt forældede erkendes vist nu almindeligt« (Rørdam 1961: 330). Sådan blev reglerne, der omfatter sagsomkostninger i straffesager, omtalt af Rørdam tilbage i 1961. Bestemmelserne om sagsomkostninger i straffesager stammer fra en ordning, der ligger forud for retsplejereformen fra 1916. Trods samfundets (teknologiske og økonomiske) udvikling har reglerne ikke gennemgået nævneværdige ændringer i den forløbne knap 100-års periode. Sagsomkostninger blev og bliver fortsat pålagt domfældte uden hensynstagen til dennes betalingsevne eller (andre) resocialiserende forhold og uden en generel mulighed for eftergivelse (Olesen 2013a). Fraværet af forbehold eller en generel eftergivelsespraksis betyder, at Danmark adskiller sig fra de fleste (hvis ikke alle andre) EU-lande og skandinaviske lande på dette område. ${ }^{2}$ Sammenlignes de danske regler med nogle af de andre skandinaviske lande, ser man, at både de norske, svenske og finske regler tilskriver, som tilfældet er i Danmark, at domfældte som udgangspunkt skal betale sagens omkostninger. Der er imidlertid forskel på, hvilke omkostninger der tilskrives som sagsomkostninger i de forskellige

* Title in English: Legal costs in criminal cases have an impact on justice, legal rights and rehabilitation. 
lande, jf. Bjerke, Keiserud \& Sæther 2011: 1430, 1432-1433 retsplejeloven, rättegångsbalk kap. $31, \S 1$, stk. 1, og forskel på om landene baserer deres praksis på undtagelser fra hovedreglen.

De norske regler er formuleret således, at omkostningsansvaret i reglen $b ø r$ pålægges domfældte, hvorved reglerne er mere lempelige end de danske, jf. strpl. $\S 436,1$. led, 1. pkt. Undtagelsesreglerne i den norske straffeprocesslov $\S \S 436$, 1. led og 437, 3. led inkluderer i modsætning til de danske regler en vurdering af sigtedes betalingsevne og en rimelighedsvurdering. Sidstnævnte medtænker bl.a. straflængde, den sigtedes alder, fysiske tilstand samt en generel vurdering af, hvorledes gældsættelsen vil indvirke på sigtedes resocialisering (Bjerke, Keiserud \& Sæther 2011: 1429). Undtagelsesreglerne bevirker, at »I praksis illeges fortsatt regelmessig domfelte små, nærmest symbolske, beløp i saksomkostninger til det offentlige« (Bjerke, Keiserud \& Sæther 2011: 1430). Ifølge svensk lov er det muligt at lempe eller eftergive sagsomkostninger efter hensynstagen til sigtedes økonomiske og personlige forhold samt den begåede kriminelle handling, jf. rättegångsbalk kap. 31, §1, stk. 4. Endvidere tilskriver de svenske regler, at omkostningerne til forsvareren, der hovedagligt er den største udgift (Rørdam 2010: 23), ikke kan overstige den retshjælpsafgift, som sigtede er forpligtet at betale i henhold til rättshjälpslagen. De svenske regler sikrer således, at omkostningerne til forsvarssalær ikke kan overstige en øvre procentsatsgrænse udregnet efter sigtedes indkomst. ${ }^{3}$

Danmarks særstatus i forhold til pålæggelse af sagsomkostninger i straffesager betyder, ifølge en opgørelse fra SKAT foretaget d. 18. januar 2013, at SKAT ultimo december 2012 har restancer fra sagsomkostninger i straffesager på 2.028 mio. kr. til inddrivelse. Gælden er fordelt på godt 60.000 skyldnere og 113.349 fordringer. Den gennemsnitlige fordring beløber sig til $17.892 \mathrm{kr}$. Gælden er i perioden 2010-2012 vokset fra 1.918 mio. kr. til 2.028 mio. kr., og inddrivelsen udgjorde i runde tal 23 mio. kr. i 2010 og 24 mio. kr. i 2012. Ifølge SKAT skyldes stigningen (af den ellers beskedne inddrivelse) en målrettet indsats på inddrivelsesområdet. Den beskedne inddrivelsesprocent vidner imidlertid om, at det er de færreste af skyldnerne, der evner at afvikle denne gæld. ${ }^{4}$

Jeg vil i det følgende diskutere nogle af de problemstillinger, der følger af de, for at anvende Rørdams ordvalg, »stærkt forældede bestemmelser om sagsomkostninger i straffesager.« Jeg diskuterer bestemmelserne ud fra tre forskellige perspektiver. Det første perspektiv, jeg behandler, fokuserer på, hvordan bestemmelserne om sagsomkostninger underminerer retlige principper som forudsigelighed, ensartethed og gennemsigtighed. Ud fra det andet perspektiv betragter jeg de retssikkerhedsmæssige udfordringer, der kan opstå, når økonomiske over- 
vejelser får en afgørende indvirkning på den strafferetlige proces. ${ }^{5}$ Det tredje perspektiv, som indgår i diskussionen om sagsomkostninger, tager udgangspunkt i de resocialiserende problematikker, der bliver affødt af at gældsætte domfældte. Jeg forsøger slutteligt at sammenfatte de retlige, retssikkerhedsmæssige og resocialiserende udfordringer ved bestemmelserne om sagsomkostninger ud fra en samfundsmæssig betragtning.

Diskussionerne bygger hovedsagligt på et empirisk materiale indsamlet til ph.d. afhandlingen Løsladt og gceldsat (2013). Materialet består af 77 dybdegående interviews med 41 flergangsdømte mænd over 18 år. Samtlige af de interviewede har erfaringer fra forudgående varetægtsfængslinger, fængselsafsoninger og løsladelser. 21 af de 41 flergangsdømte blev fulgt over en periode på maksimalt 2,5 år, der inkluderede deres løsladelse. Derudover blev der foretaget en del uformelle observationsstudier i forbindelse med interviewene og gennemført flere uformelle telefonsamtaler, sms- og e-mailkorrespondance med de løsladte og pårørende igennem hele observationsperioden (Olesen 2013b: 66-67). De interviewede flergangsdømte anslog deres sagsomkostninger til at udgøre mellem $72.000 \mathrm{kr}$. og flere millioner kr. (Olesen 2013b: 131).

\section{De retlige problemstillinger ved sagsomkostninger}

Det følgende afsnit behandler nogle af de retlige problemstillinger, der følger af reglerne vedrørende sagsomkostninger i straffesager. Førstegangstiltaltes uvidenhed om den personlige hæftelse for sagsomkostninger i straffesager udgør den problemstilling, jeg vil indlede med at diskutere. Dernæst bliver den uensartede praksis bag udregningen af sagsomkostninger og driftsudgifter behandlet. Den tredje problematik, der bliver diskuteret, er den uigennemsigtighed, der kendetegner pålæggelsen af sagsomkostninger i forbindelse med domsafsigelsen, hvor hverken dommer, anklager eller forsvarer er fuldt ud oplyst om sagsomkostningernes fulde størrelse. Dertil kommer udfordringerne med ringe klagevejledning og dårlige muligheder for at påklage en afgørelse. Den teknologiske indvirkning på uensartetheden og uigennemsigtigheden af sagsomkostninger i straffesager bliver belyst $\mathrm{i}$ afsnittets sidste del.

\subsection{Straffesagens uforudsete omkostninger}

Der kan stilles spørgsmålstegn ved, hvor udbredt kendskabet til den personlige hæftelse for straffesagens nødvendige omkostninger er blandt førstegangstiltalte. De beskikkede forsvarer skal ganske vist oplyse den tiltalte om de potentielle sagsomkostninger ud fra et standardiseret klientbekræftigelsesbrev, ${ }^{6}$ men det forekommer uklart, om disse oplysninger bliver forstået af de førstegangstiltalte el- 
ler kommunikeret på en forståelig måde (se også Jørgensen 2004: 3, 6). Studiet Løsladt og gaeldsat belyser, at 38 ud af 41 førstegangstiltalte ${ }^{7}$ var uvidende om, at de var forpligtiget til at erstatte straffesagens nødvendige omkostninger, såfremt de blev kendt skyldige (Olesen 2013b: 130-133). Det vides ikke, om denne uvidenhed bygger på misforståelser eller utilstrækkelig kommunikation mellem forsvarer og tiltalte om det klientbekræftelsesbrev, hvoraf de vejledende takster for salærer til forsvarere i straffesager fremgår i vedlagte bilag. De frihedsberøvede, der indgik i studiet, oplevede imidlertid ikke, at forsvarene oplyste dem om den potentielle udgift, der er forbundet med en straffesag. De interviewede berettede derimod, at de som førstegangstiltalte enten blev gjort opmærksomme på gælden vedrørende sagsomkostninger gennem samtaler med fængselsbetjente og medindsatte eller først blev bekendt med deres gældsposition i forbindelse med opkrævningen af sagsomkostninger under eller efter deres fængselsafsoning (ibid.).

Uvidenheden blandt de fleste førstegangstiltalte om at være forpligtet til at erstatte sagens nødvendige omkostninger kan bl.a. skyldes den måde, hvorpå de førstegangstiltalte oplever at blive præsenteret for begrebet beskikkede forsvarer. Den frihedsberøvede Sølver ${ }^{8}$ fortæller f.eks., at:

»(...) jeg kan heller ikke forstå, da jeg røg i spjældet, der siger de til mig >Sølver, du har ret til en advokat. Har du ikke råd til en, så får du beskikket en og bla, bla, bla.< Men hvorfor får jeg så en regning på 80.000? Så kan det sgu da være lige meget. (...) hvordan kan man så sende en regning for det bagefter? Hvorfor skal de stå, og fyre al det der lort af, for det kan da gøre lige meget. (...) som jeg forstod det, så hvis du ikke har råd til en advokat, så kan vi beskikke en til dig. Det er det samme som at sige, at så får du en alligevel, og så koster det dig ikke noget. Men nej, nej. Du kommer til at betale nøjagtig det samme, som hvis du havde haft råd« (Olesen 2013b: 132).

Flere førstegangstiltalte tror således, at deres beskikkede forsvarer er dem omkostningsfri. De oplever at være blevet fastholdt i en uoplyst situation, hvilket bl.a. medvirker til, at størstedelen betragter pålæggelsen af sagsomkostninger som en ekstra, uformel straf. Den uformelle straf adskiller sig fra den formelle, retlige forståelse af straf, som omfatter fængsel og bøde (Christie 2004). Den uformelle straf kan således være et eksempel på forskellen mellem nedskreven ret og oplevet ret, ${ }^{9}$ hvor de involverede parter (i dette tilfælde de domfældte) oplever pålæggelsen af sagsomkostninger, som straffende, hvilket ikke anerkendes ud fra en formel, retlig tænkning. Den uformelle straf kan i dette (og andre) tilfælde betragtes som tilsigtede virkninger af den formelle straf (se også Travis 2002: 15-36, 2005: 64 og Travis \& Waul 2003, Kaiser 2012). 
I førnævnte studie bliver det også belyst, at de interviewede frihedsberøvede udvider deres kendskab til sagsomkostninger i takt med deres øgede erfaringsgrundlag med fængselslivet. Men det øgede erfaringsgrundlag betyder ikke, at de flergangsdømte nødvendigvis ved, hvilke udgifter der beregnes som sagsomkostninger, eller hvordan udgifterne er takseret. Størstedelen af de interviewede er trods deres erfaringer fra forudgående fængselsdomme uvidende om, at sagsomkostninger inkluderer samtlige af den konkrete straffesags nødvendige omkostninger. De tror i stedet, at sagsomkostninger kun inkluderer forsvarssalæret. Den flergangsdømte Tamas henviste til en samtale han kort forinden vores interview havde haft med sine medindsatte om beregningen af sagsomkostninger: »(...) der har vi lige siddet og diskuteret, hvad man egentlig betaler for, og det ved jeg stadigvæk ikke den dag i dag, og det er min tredje dom ikke« (Olesen 2013b: 133). Den unge Manly, der også har afsonet flere fængselsdomme og skylder omkring $250.000 \mathrm{kr}$. i sagsomkostninger, udtrykte ligesom Tamas sin undren over hvilke udgifter, der medregnes som sagsomkostninger: »(...) en ting er advokatregningen, noget andet er sagsomkostningerne, jeg ved simpelthen ikke hvad det er«. Manly spørger forvirret, om han skal erstatte udgifter til »(...) jurymedlemmer og dommere og f.eks. sikkerheden omkring retsmøderne? « (Olesen 2013b: 135). En større gruppe af flergangsdømte har således ikke nogen indsigt $i$, hvilke udgifter de er forpligtiget til at erstatte det offentlige udover deres forsvarssalær. Men forsvarssalæret kan også virke forvirrende for flere af de flergangsdømte. Uden kendskab til de vejledende takster for salær og forsvarerens tidsberegning, er det umuligt for de frihedsberøvede at skabe et overblik over det potentielle skyldsbeløb de måtte blive påkrævet ved en domfældelse (Olesen 2013b: 134-135). Man kan vælge at anskue de flergangsdømtes uvidenhed som et udtryk for deres ligegyldighed, men Charles, som er flergangsdømt, understreger, at den passive rolle som flere flergangsdømte anlægger over for sagsomkostningsspørgsmålet skal betragtes ud fra den aktuelle kontekst, de frihedsberøvede befinder sig i samt det ulige dominansforhold mellem forsvareren og den frihedsberøvede:

»(...) psykologisk set er man ikke gearet til at tage stilling til det økonomiske, det kommer så langt nede af listen. Og selvom ens advokat måske hverken gør fra eller til, og han er et usandsynligt dyrt bekendtskab, så er han den eneste, du har på dit hold, det er din advokat. Og du vil ikke af med den eneste gode ven, du har. Det er jo dit liv, de sidder med i deres hænder, så de har ligesom krammet på en, og så er det ikke lige der, man bliver uvenner over prisen « (Olesen 2013b: 134). 
Sagsomkostninger i straffesager bliver således set som en uforudset udgift for de førstegangstiltalte. Som flergangsdømt er kendskabet til forpligtigelsen til at erstatte straffesagens nødvendige omkostninger større, men de flergangsdømte ved fortsat ikke, hvilke udgifter (foruden forsvarssalæret) der medregnes som sagsomkostninger, de kender ikke de vejledende takster for salæret og ej heller forsvarerens tidsberegning. Når den umiddelbart største postering i den samlede sagsomkostningsberegning går til den frihedsberøvedes tætte relation, forsvareren, kan det virke overordentligt vanskeligt at få skabt indsigt i og overblik over sagsomkostningerne. ${ }^{10}$

\subsection{Sagsomkostningernes uensartethed}

Det må anses som væsentligt, at der forelægger en ensartet anvendelse af bestemmelserne om at pålægge domfældte at betale sagsomkostninger. Det nuværende system opgør groft sagt omkostningerne ved straffesager i to posteringer: 1) de almindelige driftsudgifter og 2) sagsomkostninger. Foruden forsvarersalær kan sagsomkostninger eksempelvis være lægefaglige personundersøgelser, retsmedicinske-, retskemiske og regnskabsmæssige undersøgelser, eksternt tekniske undersøgelser, brandtekniske-, motorkøretøjs-, lægefaglige og retsmedicinske erklæringer samt Retslægerådets erklæringer, jf. rpl. kap. 91 (lbk. nr. 1139/2013). ${ }^{11}$ Disse udgifter skal som hovedregel erstattes af domfældte. Driftsudgifter, der afholdes af staten, udgør bl.a. politiets egne tekniske undersøgelser og sagkyndige erklæringer, rejsegodtgørelser og dagpenge til personale, nævninge, domsmænd og statsadvokaterne, godtgørelser til vidner, syns- og skønsmænd, tolkeudgifter og tilvejebringelse og vedligeholdelse af kontorer, retslokaler og politistationer m.m. ${ }^{12}$

Det fremgår ikke af retsplejeloven hvilke økonomiske foretagender i en given straffesag, der er nødvendige, og hvilke der er unødvendige. Disse omkostningsbebyrdende til- og fravalg beror på praksis og afgøres af politiet (Jørgensen 2004: 3). Ifølge politiets idegrundlag skal medarbejderne inddrage økonomiske og ressourcemæssige overvejelser i deres planlægning, tilrettelæggelse og udførelse af opgaver (Dansk politi 2004), men praktikere på området påpeger, at omkostningsspørgsmålet ikke indgår med nogen særlig vægt i efterforskningen (Jørgensen 2004: 5, 9; Skjødt 2004: 17-18).

Det kan i nogle tilfælde være ganske vanskeligt at afgøre, hvorvidt en udgift skal beregnes som en driftsudgift eller sagsomkostning. Eksempelvis er indledende tekniske eller regnskabsmæssige undersøgelser i en efterforskning en driftsudgift, mens tekniske eller regnskabsmæssige undersøgelser af forbrydelsens art og omfang tilskrives som sagsomkostninger (se lignende svært skelnende 
eksempler på driftsudgifter og samsomkostninger i Nautrup 1995: 80-81 og Nautrup 1984: 79). Den vanskelige skelnen mellem driftsudgifter og sagsomkostninger bliver angiveligt ikke mindre og ej heller mere ensartet og konsekvent af, at politiet skal afholde nogle af driftsudgifterne over deres rådighedsbeløb. I tilfælde hvor der hersker usikkerhed om en udgifts korrekte budgettering (eller sidst på regnskabsåret/kvartalet) må det være fristende at tilskrive udgiften som en sagsomkostning (se også Nautrup 1995: 80). Nautrup fastslår, at der næppe kan »(...) være tvivl om, at der i de forskellige politikredse følges en meget uensartet praksis vedrørende spørgsmålet om driftsudgift/sagsomkostning (...) selv inden for samme embede kan der være forskel på den administrative praksis alt efter, hvem der er sagsbehandler« (Nautrup 1995: 81).

Opkrævningen af sagsomkostninger bliver som udgangspunkt ikke underlagt en juridisk vurdering (Nautrup 1995: 80), og Nautrup opsummerer problemstillingerne ved den uensartede behandling af sagsomkostninger ved at fastslå, at »beslutningen om at iværksætte efterforskningsskridt, der medfører sagsomkostninger, og den videre sagsbehandling af udgifterne, træffes på alle niveauer. Dette kan føre til vilkårlighed med hensyn til hvilke beløb, der pålægges domfældte som sagsomkostninger« (Nautrup 1995: 81).

Bekymringen over uensartetheden i udregningen af sagsomkostninger bliver blot forstærket, når vi retter blikket mod den praktiske, uigennemsigtige fremgangsmåde i domsforhandlingerne.

\subsection{Sagsomkostningernes uigennemsigtighed}

De involverede parter i en domsforhandling kender som udgangspunkt kun forsvarssalæret og ikke de samlede sagsomkostninger, når forhandlingerne finder sted, fordi anklagemyndigheden kun har pligt til at oplyse om sagsomkostninger af usædvanlig karakter (Nautrup 1995: 79). I praksis betyder dette, at hverken anklageren eller forsvareren er bekendt med det omkostningsbeløb, den domfældte kan blive pålagt at betale (Jørgensen 2004: 7). Dommeren er endvidere udvidende om omkostningsbeløbet, der pålægges domfældte, og desuden ikke i stand til at begrunde omkostningerne og vurdere om disse står i åbenbart misforhold til domfældtes skyld og vilkår, jf. rpl. § 1008, stk. 4 (lbk. nr. 1139/2013). Skjødt stiller sig kritisk over for denne praksis:

»(...) Det har alene beroet på en praksis i anklagemyndigheden og politiet, at man har ventet med at opgøre og opkræve sagsomkostninger til efter sagen. Denne fremgangsmåde kan meget vel være historisk betinget (...) Er denne praksis ikke ude af trit med behovet for større kontrol med 
de efterhånden ikke ubetydelige sagsomkostninger, der væltes over på domfældte?« (Skjødt 2004: 18).

Nautrup stiller sig ligeledes kritisk over for omtalte praksis og udtrykker, at »Det kan undre, at domstolene vedrørende sagsomkostningerne afsiger en dom in blanco« (Nautrup 1995: 79). Nautrup påpeger endvidere, at den traditionelle begrundelse for, at sagsomkostninger ikke bliver fremlagt i forbindelse med domsafsigelsen, skyldes, at man tidligere ikke kendte samtlige sagsomkostninger på domafsigelsestidspunktet. Dette er dog sjældent tilfældet i dag, da afsoningsomkostninger pr. 1. juni 1994 ikke længere blev tilskrevet domfældte. Desuden hører det til sjældenhederne, at der efter domsafsigelsen fremkommer yderligere sagsomkostninger (Nautrup 1995: 79).

Den sparsomme juridiske litteratur om sagsomkostninger i straffesager argumenterer stort set enstemmigt for, at tiltalte mangler klagevejledning og forbedrede muligheder for at påklage en afgørelse. Jørgensen problematiserer bl.a., at det er forsvareren, der skal varetage klagevejledningen, da forsvareren alene er bekendt med forsvarssalærets størrelse, men derudover ikke kender de øvrige omkostninger, som domfældte bliver pålagt. ${ }^{13}$ Grundet de manglende oplysninger om det samlede sagsomkostningsbeløb er klagefristen på 14 dage efter domsafsigelsen ofte overskredet inden domfældte har haft mulighed for at gøre indsigelser mod kravet (Advokatrådets Strafferetsudvalg 2012). Foruden klagers og klagevejlederens uoplyste grundlag anser Jørgensen også forsvareren for at være en inhabil klagevejleder, da forsvarssalæret netop kan være det krav, domfældte ønsker påklaget (Jørgensen 2004: 8). En omvendt, men på sin vis lige så ustabil »alliance« for den domfældte bliver aktuel i de sjældne tilfælde, hvor anklagemyndigheden bliver inddraget i salærfastsættelse, og således bistår domfældtes interesser over for den beskikkede forsvarer (ibid.).

Politiets opkrævningsarbejde foregår på den måde, at de sender en skriftlig opfordring til skyldneren om inden 20 dage at indbetale det skyldige beløb, jf. bødebekendtgørelsens $\S 3$, stk. 3, nr. 1 (bek. nr. 1022/2005). Som udgangspunkt er opkrævningen ikke udspecificeret, hvilket betyder, at skyldner ikke ved, hvad opkrævningen dækker over. Flergangsdømte Anfred eksemplificerer denne oplevelse:

I: »(...) det var bare et girokort, der skulle betales over tre gange.

AO: (...) hvor meget lød den på?

I: Jeg tror, det var 150.000 (...) over tre gange. Det har jeg grint meget af« (Olesen 2013b: 239240). 
Cedric kommenterer som flere af de interviewede flergangsdømte i studiet Løsladt og gaeldsat sin forundring og mistillid til den uspecificerede opkrævning:

»Normalt når man bruger 85.000, så får man en kvittering på, hvad pengene blev brugt til. Når man køber en håndværker, så står der timeantal og kørsel, ikke. Og det gør der ikke på det der. Han [forsvareren] kunne lige så godt have skrevet 200.000, og hvad kunne jeg have sagt?« (Olesen 2013b: 133).

Det skal til de domfældtes skepsis og eventuelle forestillinger om misbrug af forsvarerens oplyste rejsedage eller besøgslængde nævnes, at der i cirkulæreskrivelsen af 1. oktober 2012 er fastsat vejledende salærtakster for forsvarere i straffesager ved byret og landsret (jf. Vejledende takster pr. 1. oktober 2012 for salærer til forsvarere i straffesager, bistandsadvokater samt til beskikkede advokater i ægteskabs-, forældreansvars- og børnefjernelsessager). ${ }^{14}$ Højesteret arbejder også ud fra vejledende takster, der medvirker til at afgrænse, hvilke arbejdsopgaver forsvareren berettiget kan kræve betaling for. De vejledende takster kan fraviges grundet sagens omstændigheder (jf. http://www.domstol.dk/hojesteret/sagsbehandling/ Pages/Slrtakster.aspx). Desuden skal forsvarere forholde sig til rejseforbehold og godtgørelse af advokaters transportomkostninger (se bl.a. Højesterets kendelse af 27. februar 2014 (sag nr. 186/2013). Retten kan ligeledes begrænse omkostningsansvaret såfremt den finder, at omkostningerne tilskrevet domfældte vil komme til at stå $\mathrm{i}$ åbenbart misforhold til vedkommendes skyld og vilkår, jf. retsplejelovens $\S 1008$, stk. 4. Denne undtagelse fra hovedreglen anvendes dog ganske restriktivt (Advokatrådets retsudvalg 2012: 3). De domfældtes mistillid til de uspecificerede opkrævninger og de korte betalingsfrister bevirker imidlertid ofte, at domfældte opfatter skyldsbeløbet som urealistisk og fiktivt, hvorfor de gerne retter en skepsis over for og modstand mod frivillige betalingsordninger og tvangsinddrivelse.

Det kan kort opsummeres, at de førstegangstiltalte i overvejende grad er uvidende om, at de hæfter personligt for straffesagens nødvendige sagsomkostninger i forbindelse med en domfældelse. Opkrævningen, som de domfældte modtager efter deres dom, er som udgangspunkt ikke udspecificeret, og de domfældte skyldnere ved derfor ikke, hvad de hæfter for. Selv efter flere domfældelser er de flergangsdømte fortsat uvidende om, hvad sagsomkostninger dækker over, og hvordan de beregnes. Ligeledes er hverken anklageren eller forsvareren bekendt med det omkostningsbeløb, den domfældte bliver pålagt at betale. Den juridiske litteratur belyser endvidere, at de tiltalte mangler klagevejledning og forbedrede muligheder for at påklage en afgørelse. De retlige problemstillinger ved bestem- 
melserne om sagsomkostninger i straffesager er således omfattende og af væsentlig karakter.

\subsection{Teknologiens indvirkning på uensartetheden og uigennemsigtigheden}

Virkningerne af sagsomkostninger i straffesager er et udtryk for den økonomiske og tekniske udvikling, der har fundet sted, siden bestemmelserne, som vi kender dem, blev vedtaget i forbindelse med retsplejereformen fra 1916. I de forløbne små 100 år er der selvsagt sket betydelige forandringer i efterforskningen af straffesager, i den strafferetlige procedure osv. Efterforskningsskridtene er blevet mere tekniske og derved også mere omkostningsfulde. Eksempler herpå er retsmedicinske undersøgelser såsom brugen af DNA-undersøgelser, som er et nyere kriminalteknisk redskab, som politiet ikke har kompetence til at forestå (se også Skjødt 2004). Et andet eksempel er brugen af eksterne regnskabsmæssige undersøgelser (revisionsrapporter), der ofte kan være ganske komplicerede, langstrakte og omkostningstunge.

Nogle udviklingstrin er udelukkende af økonomisk karakter, som da man pr. 1. okt. 1978 besluttede at øge sagsomkostningerne væsentligt, ved at indføre moms af forsvarssalæret (Nautrup 1984: 88, note 77). De finansielle tilskrivninger er mindre synlige $i$ andre udviklingstrin som f.eks. ved brugen af videokonferencer til politiafhøring og retsmøder for behandling af fristforlængelse. Brug af videokonferencer vil alt andet lige reducere de (online) fremmødtes transportudgifter, og det er vel næppe hensigtsmæssigt, at nogle tiltalte kan spare penge på at få behandlet deres sag i en politikreds, som helliger sig den nyeste teknologi, mens der ikke kan opnås den samme besparelse i andre politikredse.

I forbindelse med udviklingstrin, der berører gæld vedrørende sagsomkostninger, bør det også nævnes, at selvom bestemmelserne om sagsomkostninger i straffesager ikke har forandret sig mærkbart, så har der fundet en væsentlig udvikling sted i forhold til opkrævnings- og inddrivelsesreglerne. Det kan nævnes, at d. 1. november 2005, blev al inddrivelse af gæld til det offentlige samlet under Skatteministeriet. Inddrivelse af gæld vedrørende sagsomkostninger i straffesager blev således overført fra politiet til SKATs Restanceinddrivelsesmyndighed (RIM), jf. opkrævnings- og inddrivelsesloven $\S 5$, stk. 2 (lov nr. 429/2005). Med ændringen blev inddrivelsesmetoderne af gæld forårsaget af strafbare forhold udvidet (for en dybdegående gennemgang af disse forandringers indvirkning på gælden vedrørende sagsomkostninger se Olesen 2013a). Inddrivelsesmetoderne er yderligere blevet skærpet med SKATs implementering af EFI (Et fælles inddrivelsessystem) i 2013 (Spørgsmål nr. 96, af 21. november 2013, samråd i Skatteudvalget vedrørende udviklingen $i$ offentlige restancer). 
Foruden de mere omkostningsfulde udviklingstrin, der direkte eller indirekte berører opgørelsen af sagsomkostninger, kan den økonomiske og teknologiske udvikling endvidere udfordre ensartetheden af udregningen af sagsomkostninger.

\section{De retssikkerhedsmassige problemstillinger ved sagsomkostninger}

Studiet Løsladt og gceldsat belyser flere retssikkerhedsmæssige problemstillinger ved bestemmelserne vedrørende sagsomkostninger i straffesager ud fra de interviewedes retrospektive beretninger som tiltalt. ${ }^{15}$ Disse bliver sammenfattet i det følgende.

For de tiltalte, der er bekendt med hvilke forhold der medregnes som sagsomkostninger i straffesager, indvirker økonomiske overvejelser på forskellig vis på deres strafferetlige proces. De oplyste tiltalte kan groft sagt betragtes som enten sparsommelige eller spenderende. Økonomiens indvirkning på processen kan på flere måder medvirke til retssikkerhedsmæssige problemer eller samfundsøkonomiske udfordringer. I dette afsnit bliver de såkaldte sparsommelige tiltaltes handlingsstrategier først belyst, hvorefter handlingsstrategierne udviklet af de såkaldte spenderende tiltalte bliver behandlet. De tiltaltes (direkte som indirekte) handlingsstrategier skal generelt betragtes ud fra de livsbetingelser og begrænsede muligheder de er underlagt (Lamaison \& Bourdieu 1986: 113). Analysen af de tiltaltes handlingsstrategier bygger således på en forståelse af, at de er frie til at vælge, men ikke er frie til at vælge de principper, de vælger ud fra (Wacquant 1989: 45).

\subsection{De sparsommelige tiltaltes brug af forsvarer og fremmøde til fristforlaengelse}

Forsvarssalæret er generelt den største udgiftspost i sammenregningen af sagsomkostninger (Rørdam 2010: 23). Derfor spekulerer nogle tiltalte i at afstå fra at benytte en forsvarer, men det er i flere tilfælde et krav uafhængigt af den tiltaltes eget ønske, at vedkommende har en forsvarer, jf. rpl. 731, stk. 1 (lbk. nr. 1139/2013). De tiltalte, der ønsker at spare på udgifterne til deres straffesag, begrænser derfor i stedet ofte deres kontakt til forsvareren. De afslår så vidt muligt at modtage opkald eller besøg fra forsvareren i weekenden samt i forbindelse med helligdage, hvor takseringen er forhøjet (jf. Vejledende takster pr. 1. oktober 2012 for salærer til forsvarere i straffesager, bistandsadvokater samt til beskikkede advokater i ægteskabs-, forældreansvars- og børnefjernelsessager, pkt. 5).

Den sparestrategi, de tiltalte betragter som den mest anvendelige, består i at undlade at møde op til de retsmøder, hvor deres fristforlængelse behandles (Olesen 2013b: 143). En varetægtsfængsling kan maksimalt strække sig over fire 
uger, hvorefter politiet enten skal løslade den varetægtsfængslede eller ved en kendelse fordre fængslingen forlænget. Salæret for et retsmøde om forlængelse af fristen for varetægtsfængslingen, hvor forsvareren har personligt fremmøde, takseres til 1.300 kr. eksklusiv moms (2012-takster). Derudover pålægges tiltalte i tilfælde af domfældelse også at betale forsvarerens rejsetid og rejseudgifter. Vælger tiltalte i stedet at erklære sig indforstået med fristforlængelsen på et skriftligt grundlag budgetteres udgiften til $800 \mathrm{kr}$. eksklusiv moms (2012-takster). ${ }^{16} \mathrm{Om}$ kring halvdelen af de interviewede foretrækker at forlænge deres frist for varetægtsfængslingen på et skriftligt grundlag. To flergangsdømte forklarer i det følgende, hvilke overvejelser de har gjort sig i forhold til deres fristforlængelser. Kees påpeger, at han »(...) kan godt se for hver måned, for hver fristforlængelse der går, det klikker jo bare deropad på regningen. (...) jeg ved, at det koster et eller andet vanvittigt hver gang« (Olesen 2013b: 143). Lucien bemærker ligeledes, at han har:

I: »(...) sparet nogle penge ved at lade være med at komme til fristforlængelserne, der har jeg sparet mange penge (...) bare i varetægtsfængsel har jeg siddet i et år ikke.

AO: Det har været meget bevidst, at du sagde nej til at komme ...?

I: Ja, det var faktisk min egen advokat, der sagde, at det syntes hun, var en dårlig ide, for så ville jeg komme til at miste en masse penge på det« (Olesen 2013b: 143).

Økonomiske overvejelser ligger således ofte til grund for, at de tiltalte anser retsmøder om forlængelse af fristen for varetægtsfængslingen og generel kontakt med forsvareren som en oplagt »spare-post $\ll$.

\subsection{De sparsommelige tiltaltes tilståelsessager}

Endnu en måde, hvorpå de tiltalte kan spare penge under deres strafferetlige proces, er ved at afgive en tilståelse. Som udgangspunkt formindskes både sagsbehandlingsdelen og efterforskningsdelen i tilståelsessager og sagen fremmes hurtigere til dom, jf. dog forbehold i rpl. $\S 831$, stk. 1 (lbk. nr. 1139/2013). Den begrænsede sagsbehandling og efterforskning betyder generelt, at tilståelsessager er mindre økonomisk bebyrdende end sager, hvor der ikke afgives tilståelse. Den flergangsdømte Romann påpeger hertil, at »Det er dyrt at nægte, og advokaten skal ind og snakke med dig igen. Han tager kraftedeme et par tusinde per gang eller et eller andet« (Olesen 2013b: 144). De økonomiske overvejelser ved at afgive tilståelse bliver oftest italesat af tiltalte i sager, hvor de var de eneste anklagede (ibid.). 
Det er vigtigt at pointere, at de flergangsdømtes overvejelser ved at afgive tilståelse både bygger på en økonomisk betragtning og en generel mistro til straffesystemet. I samtalerne med de flergangsdømte, der har afgivet eller har overvejet at afgive tilståelse i deres straffesag(er), bliver de økonomiske argumenter sammenholdt med den systemmistillid, de har oparbejdet gennem tidligere straffesager. Christer bemærker eksempelvis, at han »(...) ikke [havde] nok tiltro til systemet, til at tro på, at jeg ikke ville blive dømt. Og så handler det jo bare om at få det overstået i en fart - både afsoningsmæssigt og økonomisk « (ibid.).

\subsection{De sparsommelige tiltaltes overvejelser over anke-reglerne}

De fleste tiltalte er som tidligere belyst uvidende om, hvilke udgifter de skal afholde i forbindelse med deres straffesag. Uvidenheden gør sig også gældende i forhold til ankereglerne, hvilket medfører nogle retssikkerhedsmæssige problemstillinger, da flere af økonomiske grunde vælger ikke at anke deres sag. Den flergangsdømte Erlin begrunder sit fravalg af at anke således:

I: »(...) sagsomkostningerne fra der og så op til den nye retssag, de bliver jo dobbelt, i forhold til det de havde været, minimum. Nu kender jeg ikke taksterne på byret og landsret, jeg ved bare at det er meget dyrere i landsretten end i byretten. Så jeg tænker 300.000 gange to plus, det bliver i hvert fald 600.000 (...).

AO: Men som du siger, du føler, at du nærmest er frifundet og så vil du alligevel ikke anke den af økonomiske årsager?

I: Det vil jeg ikke« (Olesen 2013b: 136).

Reglerne for anke foreskriver, at udgifter, der er foranlediget af anke, skal erstattes af tiltalte, såfremt anken er foranstaltet af tiltalte og udfaldet forbliver uændret eller mere ugunstigt for tiltalte, jf. rpl. § 1008, stk. 3 (lbk. nr. 1139/2013). Anke af straffesager bliver derfor af flere tiltalte nøje overvejet ud fra økonomiske betragtninger.

De retssikkerhedsmæssige problematikker ved ankereglerne og den personlige hæftelse for sagsomkostninger består dog ikke alene i, at de tiltalte medtænker et økonomisk incitament i procesførelsen af deres straffesag, men også i at domfældte i flere tilfælde skal erstatte det offentlige for udgifter til anke, selvom det ikke er domfældte, der har foranlediget anken. Rørdam understreger, at:

»Den formentlig mest åbenbare urimelighed ved den gældende ordning er, at tiltalte skal betale sagens omkostninger i anken, selvom det alene er anklagemyndigheden, der anker, når anken får et for tiltalte skadeligt resultatet, og det således er underretterens fejlagtige bedømmelse af sagen i første instans, der har ført til anken« (Rørdam 1961: 330). 
Ankereglerne er for flergangsdømte Mejnert og andre i samme situation fuldstændig uforståelige:

»Jeg syntes da, det er dyrt, det er vildt dyrt at komme i landsretten. F.eks. i min sag her der røg jeg i byretten, hvor Anklagemyndigheden de anker, så skal jeg betale for landsretten også, det er måske ikke helt i orden. Jeg har jo sådan set fået min dom i byretten, og der fik jeg halvandet år, og så kan jeg jo ikke gøre for, at de ikke syntes, at jeg har fået nok, og så skal i landsretten. Det brokkede jeg mig lidt over, men det hjælper jo ikke noget (...) jeg kunne forstå, hvis jeg selv havde anket, så er det jo mig selv, der vil videre, men det er dem, der syntes, at jeg skal have mere, og så syntes jeg, det er lidt ærgerligt, at jeg skal betale. (...) jeg går ud fra, at man bare skal betale det hele? Jeg tror bare, det bliver lagt sammen, tror du ikke?« (Olesen 2013b: 135).

Beslutter Anklagemyndigheden at anke en dom, er tiltalte fortsat forpligtiget til at erstatte sagens omkostninger, såfremt resultatet af anken fører til et mere ugunstigt resultat for tiltalte, jf. jf. rpl. § 1008, stk. 3 (lbk. nr. 1139/2013). Mejnerts dom blev skærpet af Landsretten fra 1,5 år til 3,5 år. De ekstra udgifter ved ankesagen, som vækker bekymring hos Mejnert, er således reelle, men ikke nødvendigvis så omfattende, som Mejnert forudser. På interviewtidspunktet har Mejnert dog endnu ikke modtaget en opkrævning over straffesagens omkostninger, hvorfor han fortsat er uvidende om, hvor meget sagen beløber sig til. Mejnert udtrykker sit syn på ankereglernes logik, da jeg er i færd med at forlade fængslets besøgslokale efter interviewet:

»Jeg skal lige fatte det her Annette. Dvs., at hvis jeg nu ikke havde fået mere i straf nu her, så skulle jeg heller ikke betale mere? Men fordi jeg skal sidde længere, så skal jeg også betale mere i sagsomkostninger? Det giver sgu da ingen mening mand. Så hvis det bliver hårdere i straffen, så bliver det også bare dyrere. Shit ...« (Olesen 2013b: 136).

Rørdams italesættelse af ankereglerne som en åbenbar urimelighed afspejler således de frihedsberøvedes oplevelser af reglerne. I modsætning til de danske regler kan sigtede ifølge norske regler ikke pålægges sagsomkostninger, når Anklagemyndigheden anker, kærer eller begærer en dom (Andenæs 2009: 607, Bjerke, Keiserud \& Sæther 2011: 1431).

\subsection{De spenderende tiltaltes brug af forsvarer}

I modsætning til de sparsommelige tiltalte har de spenderende tiltalte ingen intentioner om at begrænse deres sagsomkostninger. Den flergangsdømte Michaell tydeliggør, hvilken økonomisk tankegang der ofte præger de spenderende tiltalte: »Jeg har det på den måde, jeg kan lige så godt tage det bedste af det bedste, for 
min lomme vil ikke komme til at mærke det, for det kan bare komme ovenpå det andet (...)« (Olesen 2013b: 145). Indirekte skildrer Michaells kommentar, hvordan gældsættelse kan medføre håbløshed, ligegyldighed og deraf afføde en rundhåndet »brug« af offentlige midler. Sagsomkostninger bliver som nævnt oplevet som en ekstra, uformel straf, og de uspecificerede opkrævninger af sagsomkostninger bliver ligeledes af flere oplevet som et »fiktivt « beløb, som skyldnerne hverken anerkender eller har i sinde at betale. I straffesager udredes omkostningerne i første omgang af det offentlige med forbehold af ret til at få dem erstattet, hvis tiltalte erkendes skyldig. Øger de tiltalte deres (potentielle) sagsomkostninger uden at have i sinde at afdrage beløbet på et senere tidspunkt, øger de samtidig det offentliges »fiktive« tilgodehavende. En bevidst udvidelse af gælden kan således forekomme i de situationer, hvor de tiltalte anser det som muligt at få et behageligere varetægtsophold ved at udvide gælden til det offentlige. Gældsudvidelse forekommer imidlertid også i de situationer, hvor de tiltalte kan besværliggøre efterforskningen, trække sagsbehandlingen i langdrag og generelt udtrykke deres systemfjendtlighed ved at udvide deres i forvejen ubetalelige gæld til det offentlige.

Forsvarssalæret er som nævnt generelt budgetteret som den største postering i beregningen af sagsomkostninger, og flere af de spenderende tiltalte beretter da også, hvordan de øger omkostningerne i deres straffesag ved at have hyppig kontakt til deres forsvarer. Den flergangsdømte Nic, der skylder omkring to millioner kroner i sagsomkostninger og erstatningskrav, beretter blandt flere, hvordan han er indforstået med at spendere på sit forsvarssalær:

I: »(...) så har jeg haft en advokat, hvor jeg har sagt, at han bare skulle skrive på. Han kom fra Aarhus, så han var ovre at besøge mig på Sjælland. Jeg sad varetægtsfængslet i to år sidste gang. Han kom en gang i ugen (...) Og der skriver han selvfølgelig [kørselsudgifter] på til alle de klienter, han er ovre og besøge, når han er på Sjælland. Så er der lige en 4-5 stykker han er rundt ved. AO: Hvorfor har du taget det valg, at det godt må blive dyrt?

I: (...) jeg er i bund og grund ligeglad, jeg har ikke tænkt mig at betale noget af det tilbage. Når jeg har fået min dom, så har jeg betalt mit til samfundet, så har jeg ikke tænkt mig at betale yderligere« (Olesen 2013b: 146).

Den økonomiske relation mellem de tiltalte og forsvareren kan generelt beklages, men relationen bliver ganske problematisk, hvis økonomi bliver styrende for samarbejdet.

\subsection{De spenderende tiltalte der anker og noegter at udtale sig}

I modsætning til de sparsommelige tiltalte, der af økonomiske årsager ikke anker deres dom, så benytter nogle af de spenderende tiltalte den omvendte »strategi«, 
hvor de uden økonomiske skrupler anker deres sag for at vinde tid i frihed. Den 22-årige Achton illustrerer brugen af ankereglerne i en samtale, hvor han som nyligt løsladt har fået en verserende sag på halsen. Til spørgsmålet om, hvordan han forholder sig til tanken om, at han risikerer at ende i fængsel igen, svarer han: »Jamen, så har jeg tænkt mig at anke den igen, så jeg kan få længere tid til at være ude« (Olesen 2013b: 345). Jeg spørger Achton, om han har overvejet det økonomiske mellemværende, en ankesag medfører, såfremt han bliver dømt i sagen, hvortil Achton svarer: »Det er friheden, der er det bedste for mig. Jeg har jo ikke været ude et halvt år, siden jeg var 18 år gammel« (ibid.). Achton og andre af de flergangsdømte anser således brugen af ankereglerne som en mulighed for at vinde tid i frihed.

En anden måde, hvorpå nogle af de tiltalte trækker straffesagen i langdrag og øger sagsomkostningerne er ved at nægte sig skyldig og nægte at udtale sig om sagen. Flere af de flergangsdømte beskriver, hvordan de, uanset hvor håbløs deres situation måtte se ud, har et princip om aldrig at tilstå. En sådan udvidelse af de offentlige udgiftsposter kan betragtes som modstand fra de tiltalte, der ofte oplever frihedsberøvelsen som særdeles handlingsbegrænsende. De tiltalte har mulighed for at reagere direkte mod systemet i de tilfælde, hvor de kender sagens udgiftsposter og formår at øge udgifterne ud fra hensigten om, at det offentlige afholder (og også i fremtiden kommer til at afholde) disse (Olesen 2013b: 146).

Handlingsstrategierne udtrykt af de sparsommelige og spenderende tiltalte tydeliggør på forskellig vis nogle problemer ved bestemmelserne om sagsomkostninger i straffesager. Når de sparsommelige tiltalte på flere måder betragter deres strafferetlige proces som en spare-øvelse, og begrænser kommunikationen med forsvareren, erklærer sig indforstået med fristforlængelsen på et skriftligt grundlag, afgiver tilståelse eller undlader at anke deres sag, er det et retssikkerhedsmæssigt problem. Når de spenderende tiltalte derimod udvider deres gæld vedrørende sagsomkostninger - ved hyppigt at anvende deres forsvarer, nægte at udtale sig og så vidt muligt anke deres sag - uden at have i sinde at tilbagebetale gældsbeløbet er det en samfundsøkonomisk udfordring.

I forlængelse af de oven for behandlede retlige og retssikkerhedsmæssige problemstillinger, der bliver affødt af reglerne vedrørende sagsomkostninger, vil reglernes indvirkning på de domfældtes livsbetingelser og resocialisering efter de har udstået deres formelle straf blive belyst i det følgende.

\section{De resocialiserende problemstillinger ved sagsomkostninger}

Reglerne vedrørende sagsomkostninger i straffesager bevirker, at størstedelen af de straffedømte i Danmark har en betydelig gæld til det offentlige, som politi og 
SKAT forsøger at inddrive efter strafudståelsen. ${ }^{17}$ De løsladtes tilværelse efter endt straf bærer således i høj grad præg af offentlige myndigheders retlige regulering af deres mere eller mindre private forhold. Det bliver i studiet Løsladt og gaeldsat belyst, at gæld kan betragtes som en risikofaktor for kriminelt tilbagefald. Påstanden lyder således ikke, at gæld er den direkte årsag til, at nogle begår ny kriminalitet, men studiet viser, at de kendte kriminalpræventive faktorer som uddannelse, arbejde og permanent bolig bliver påvirket i negativ retning af gælden (Olesen 2013b).

De løsladtes gældssituation bevirker, at SKAT kan inddrive en procentdel af deres officielle indkomst, så de uanset om de har et fuld/deltidsjob eller modtager sociale ydelser vil have et nogenlunde identisk rådighedsbeløb hver måned, indtil de har betalt deres gæld. De løsladte oplever på den måde ikke nogen aktuel, økonomisk profit af at være i arbejde frem for at være offentligt forsørget. Forskellen på den hårdtarbejdende løsladte og den offentligt forsørgede løsladte er altså, at den hårdtarbejdende bliver gældfri før den offentligt forsørgede, men derudover er deres økonomiske situation i store træk den samme. Studiet viser, at flere af de flergangsdømte har gæld, som de anser for at være uoverskuelig og ubetalelig, og at gælden må betragtes som en væsentlig hindring for, at de ikke søger tilbage på det officielle arbejdsmarked. De løsladte ender derfor ofte med at modtage offentlige ydelser eller søge fuld/deltidsbeskæftigelse i brancher, hvor de kan tjene sorte penge og undgå SKATs gældsinddrivelse. Alternativt genoptager nogle deres kriminelle livsstil (Olesen 2013b: 301-307).

Gælden modvirker desuden motivationen for at påbegynde/færdiggøre en uddannelse, fordi deres gældssituation bevirker, at de alligevel ikke kan omsætte en uddannelse til en stabil økonomisk fremtid (Olesen 2013b: 163-165).

Gælden begrænser også de løsladtes grundlag for at lade sig registrere på en bopæl. Studiet synliggør, hvordan de gældsatte løsladte kun har ret til et »simpelt hjem« og en »simpel levefod «. Det betyder, at alle ejendele, der ikke er decideret nødvendige, (som fx en seng, et bord, en stol, et billigt fjernsyn osv.) kan pantefogeden gøre udlæg i (Olesen 2013b: 221-224, 262-272). Politiet kan også udføre ransagninger i de løsladtes hjem og beslaglægge pengebeløb og genstande af en vis værdi til tvangsinddrivelse (Olesen 2013b: 273-279). Både pantefogedens og politiets bestræbelser går ud på at få afskrevet de løsladtes gæld så hurtigt og effektivt som muligt. Den overhængende risiko for ubehageligt besøg af pantefogeden og politiet begrænses betydeligt, hvis de løsladte ikke benytter en registreret folkeregisteradresse, fordi de alt andet lige bliver sværere at finde. Gældsættelsen af de løsladte har en negativ indvirkning på flere kriminalpræventive faktorer og må således betragtes som en risikofaktor for recidiv. 
Et andet centralt fund i studiet er, at gældsættelsen rammer de løsladte, der ønsker at blive en aktiv del af samfundet og påvirker i mindre grad de løsladte, der genoptager en kriminel livsstil. Gældsættelse betyder, at vejen fra fængsel tilbage til samfundet er problemfyldt, og for flere løsladte er en kriminalitetsfri tilværelse ikke noget at stræbe efter. De løsladte, der forsøger at leve kriminalitetsfrit, oplever derimod i højere grad de negative følger af tvangsinddrivelsen i deres officielle indkomst, og de negative følger af besøg fra pantefogeden og politiet på deres registrerede folkeregisteradresse (Olesen 2013b: 345-355).

Studiet viser, hvordan de løsladte, der genoptager en kriminel livsstil, er dygtige til at etablere og indgå i et »parallelt samfund«. På fornem vis navigerer de kriminelt aktive uden om de institutioner og offentlige systemer, der på grund af deres gældssituation udfordrer dem og giver dem problemer. De kriminelt aktive finder bl.a. deres vej udenom systemet ved at anvende en uofficiel økonomi, et alternativt sikkerhedsnet og alternative ejerskabs- og boligforhold (Olesen 2013b: 115-118, 221-224, 267-271, 307). Det parallelle samfund og den alternative livsstil kompenserer på den måde for de negative følger af gældsættelsen, de løsladte møder efter endt fængselsstraf (Olesen 2013b: 328-337). Så selvom der er mange ulemper ved ikke at være en del af det registrerede samfundet, så oplever flere af de løsladte, at gældsættelsen og den heraf følgende retlige regulering er så uoverskuelig, at de foretrækker den livsstil og de udfordringer, de møder i et kriminelt miljø.

Gældsættelsen rammer altså i mindre grad de kriminelt aktive og i større grad de løsladte, der afholder sig fra at begå ny kriminalitet og ønsker at indgå aktivt i samfundet. Gældsættelsen af de løsladte modvirker således det resocialiserende arbejde med tidligere straffedømte.

\section{Sammenfatning og en samfundsmassig betragtning}

De danske regler om sagsomkostninger i straffesager er blevet studeret og diskuteret indgående af forskere, fagfolk og politikere igennem de seneste år, og gennemarbejdede ændringsforslag er blevet fremsat. ${ }^{18} \mathrm{I}$ den juridiske litteratur er det blevet belyst, hvordan reglerne, der omfatter sagsomkostninger i straffesager, medfører betydelige retlige problemstillinger, specielt i forhold til manglende forudsigelighed og gennemsigtighed i forbindelse med pålæggelsen af sagsomkostninger, uensartethed i udregningsprocessen, begrænsede muligheder for at påklage en afgørelse og ringe klagevejledning. Vi er desuden blevet gjort opmærksomme på, at reglerne også afføder en del utilsigtede retssikkerhedsmæssige og resocialiserende problemstillinger. Spørgsmålet er så, om vores nye viden på området har gjort tiden moden til at ændre de ældre bestemmelser? Nautrup 
understregede allerede i 1984 vigtigheden af en >cost-benefit sagsomkostninger, som ikke er nogen straf (Nautrup 1984: 84). Det kan altså være relevant at stille spørgsmålstegn ved, hvad det danske samfund mister eller vinder ved at nærme sig nogle af de bestemmelser, der findes i de andre EU-lande og skandinaviske lande, hvor pålagte sagsomkostninger bl.a. er vurderet ud fra resocialiserende hensyn, betalingsevne og/eller reelle eftergivelsesmuligheder (Eyben 1960: 219-221, Sørensen \& Singh 2010: 43-53, Advokatrådets retsudvalg 2012: 9-11).

I en dansk kontekst må nogle af de tungeste argumenter for at bevare de gældende regler vedrørende sagsomkostninger i straffesager utvivlsomt være af økonomisk karakter og henvise til befolkningens og ofrenes retsfølelse. De økonomiske argumenter foreskriver, at det ikke kan være andet end rimeligt, at domfældte selv dækker omkostningerne ved straffesagen, da denne udgift ellers vil tilfælde statskassen. Men da sagsomkostninger i første omgang udredes af det offentlige med forbehold af ret til at få dem erstattet, og det blot er en beskeden del af det samlede gældsbeløb til sagsomkostninger, der bliver inddrevet hos de ofte økonomisk underprivilegerede domfældte, ${ }^{19}$ tilfalder størstedelen af omkostningerne alligevel det offentlige. ${ }^{20} \mathrm{Vi}$ ved desuden, at flere af de frihedsberøvede som en modreaktion på deres gældsættelse bevidst forsøger at øge det offentliges omkostninger til deres straffesag, fordi de ikke har i sinde at betale beløbet tilbage, og derfor lige så godt kan bruge deres forsvarer så meget så muligt, nægte at udtale sig, anke deres sag m.m. (jf. afsnit $3.4 \mathrm{og}$ 3.5). Gælden vedrørende sagsomkostninger kan således ud fra et samfundsmæssigt perspektiv betragtes som et fiktivt tilgodehavende i det offentlige regnskab, der på forskellig vis øger de offentlige udgifter til forfølgelse af straffesager.

Hensynet til befolkningens og ofrenes retsfølels $e^{21}$ er desuden et ofte anført argument for, at domfældte skal pålægges at betale sagens omkostninger - og at de som udgangspunkt ikke skal havde mulighed for at få denne gældstype eftergivet (jf. Larsen 2009: 19-27, 32, Hindborg 2006: 147-148, 179, 184-185 og besvarelse af spørgsmål nr. 4 af 10. oktober 2008 fra Folketingets Retsudvalg til justitsministeren, forslag til lov om inddrivelse af gæld til det offentlige (L 20)). Spørgsmålet, der trænger sig på, er imidlertid, om befolkningen og ofrene er bekendt med de regler, der vedrører sagsomkostninger. Og et ikke mindre væsentligt spørgsmål er, om befolkningen og ofrene er bekendt med de retssikkerhedsmæssige og resocialiserende problemstillinger, som sagsomkostningerne afføder. Man kunne forestille sig, at befolkningen og ofrene er lige så uvidende om bestemmelserne, som det har vist sig, at de førstegangstiltalte er - og er det så overhovedet muligt at føle (vide/vurdere) noget, når man ikke ved, at det (bestemmel- 
serne) eksisterer? ${ }^{22}$ Jeg skelner i denne forbindelse ikke mellem befolkningens og ofrenes generelle eller informerede retsfølelse, men stiller derimod spørgsmålstegn ved, om en retfølelse kan udledes uden en følelse.

Omvendt må nogle af de tungeste argumenter for at ændre de gældende regler vedrørende sagsomkostninger i straffesager utvivlsomt (også) være af økonomisk karakter og med henvisning til befolkningens og ofrenes retsfornuft. ${ }^{23}$ De økonomiske argumenter bygger i den henseende på, at gæld er en risikofaktor for recidiv, og både fængselspladser og resocialiserende tiltag er dyre. Samfundet vil derfor antageligt kunne drage større fordel af diverse omkostningstunge resocialiserende initiativer, såfremt reglerne om sagsomkostninger bliver fjernet/lempet (jf. Betænkning om sagsomkostninger i straffesager, Betænkning nr. 1547/2014). Forskning har desuden gjort os opmærksomme på, at reglerne bidrager til, at flere løsladte lever af offentlig forsørgelse og flere ernærer sig ved sorte penge, hvilket tærer på statskassen. Gældens indirekte indvirkning på ny kriminalitet betyder alt andet lige også, at flere borgere bliver ofre for ny kriminalitet. Det bliver ud fra denne betragtning relevant at henvise til befolkningens og ofrenes retsfornuft. For det må antages, at reglerne vedrørende sagsomkostninger og de heraf afledte utilsigtede retssikkerhedsmæssige og resocialiserende problemstillinger, som domfældte møder efter endt formel straf, strider mod den danske befolknings retsfornuft.

\section{Noter}

1. Annette Olesen, ph.d., er adjunkt i retssociologi ved Juridisk Institut, Syddansk Universitet.

2. Se Notat fra Advokatrådets strafferetsudvalg vedrørende sagsomkostninger i straffesager, bilag nr. 274 af 20. april 2012 fra Folketingets Retsudvalg til justitsministeren og Sørensen \& Singh 2010.

3. For illustrerende eksempler på hvordan de svenske regler med en øvre procentsatsgrænse for pålæggelsen af omkostninger til forsvarssalær kan virke i en dansk kontekst se Sørensen \& Singh 2010: 52-53.

4. Gælden kan ikke inddrives, såfremt RIM via en betalingsevneberegning fastslår, at skyldnerne kun har, hvad der svarer til eller mindre end RIMs fastsatte rådighedsbeløb (jf. bekendtgørelse om inddrivelse af gæld til det offentlige § 5, stk. 3 (bek. nr. 922/2011). Skyldnerne får i sådanne tilfælde henstand med betaling.

5. Jeg vil i nærværende artikel ikke indlede en diskussion om, hvorvidt reglerne vedrørende sagsomkostninger i straffesager strider mod menneskerettighedskonventionens artikel 6, stk. 3, litra c, selvom dette emne ville være af relevant betydning. (Se fx Werlauff 1993).

6. Se også bekendtgørelse om vejledning af sigtede om adgangen til at begære en forsvarer beskikket $\S 2$, stk. 2 (bek. nr. 467/1978).

7. Studiet omhandler flergangsdømte, hvorfor de udtaler sig om deres oplevelser som førstegangsfrihedsberøvede i et retrospektivt perspektiv. 
8. De interviewedes navne er anonymiseret og erstattet af pseudonymer, der er tilfældigt udvalgt via en navnedatabase med traditionelle og utraditionelle navne, jf. http://1001line.dk/navne.

9. Se bl.a. studierne af Sarat (1990), Merry (1990) og Ewick \& Silbey (1998) der omhandler oplevet ret.

10. Praktikere anslår advokatsalæret til at udgøre minimum 90 pct. af de samlede sagsomkostninger, jf. Rørdam 2010: 23.

11. For en udførlig gennemgang af sagsomkostninger i straffesager se Sørensen \& Singh 2010; Gomard 2013: 615-34; Nautrup 1984: 76; Jørgensen 2004: 3-4, 9; bekendtgørelse om takstmæssigt fastsatte sagsomkostninger i straffesager (bek. nr. 371/1977).

12. Driftsudgifterne reguleres i bekendtgørelse af lov om udgifterne i strafferetsplejen (lbk. nr. 744/1986); cirkulære om afholdelse af udgifter til tolkning $§ 2$ (cir. nr. 104/1989); EMRK art. 6, stk. 3, litra e, rpl. § 1008, stk. 4 og 5 (lbk. nr. 1139/2013). Se også Sørensen \& Singh 2010: 19-20; Jørgensen 2004: 3; Nautrup 1984: 76; Nautrup 1995).

13. Omkostningsspørgsmålet kan dog indbringes for retten i medfør af rpl. §998 (lbk. nr. 1063/2011).

14. Forhøjelser af de vejledende takster kan bl.a. forekomme i bevistunge sager såsom nævningesager, hvorimod takst-nedsættelse f.eks. kan forekomme i sager, der afløser hinanden og involverer den samme forsvarer, jf. Vejledende takster pr. 1. oktober 2012 for salærer til forsvarere i straffesager, bistandsadvokater samt til beskikkede advokater i ægteskabs-, forældreansvars- og børnefjernelsessager, pkt. 14.

15. For en uddybning af tidsaspektet og brugen af de interviewedes retrospektive oplevelser jf. Olesen 2013a: 64-66.

16. Jf. Vejledende takster pr. 1. oktober 2012 for salærer til forsvarere i straffesager, bistandsadvokater samt til beskikkede advokater i ægteskabs-, forældreansvars- og børnefjernelsessager.

17. De løsladte har ofte gæld til både private-, offentlige- og »gade«-kreditorer, hvorfor gældssituationen kun sjældent alene kan tilskrives gælden vedrørende sagsomkostninger (Olesen 2013b: 241-254).

18. Jf. forslag til folketingsbeslutning om mulighed for eftergivelse af sagsomkostninger i straffesager fremsat af Socialistisk Folkeparti, B 56, d. 22. februar 2011. Det blev foreslået, at der bliver skabt mulighed for, at der kan ske hel eller delvis eftergivelse af sagsomkostninger i straffesager efter endt afsoning, herunder at der skal ske eftergivelse af sagsomkostninger i straffesager for personer, som ikke har begået ny kriminalitet i en periode på fem år efter endt afsoning. 1. behandling af folketingsbeslutningen er afsluttet, og der er nedsat en arbejdsgruppe af Justitsministeriet. Advokatrådets strafferetsudvalg har i sit forslag til ændringer af reglerne vedrørende sagsomkostninger i straffesager foreslået, at: 1) »(...) retsplejelovens regler om sagsomkostninger i straffesager ændres således, at retten i en straffesag skal pålægge den dømte sagsomkostninger ud fra en vurdering af den domfældtes evne til at betale på domsafsigelsestidspunktet«, 2) »(...) overveje en regel om, at idømte sagsomkostninger kan eftergives, såfremt den dømte holder sig kriminalitetsfri i 3 år efter dommen/endt afsoning (...) 3$) »(. .$.$) alle sagsomkostninger (...) skal foreligge oplyst på domsafsigelsestids-$ punktet. I modsat fald kan disse omkostninger ikke gøres gældende. « (Notat fra Advokatrådets strafferetsudvalg vedrørende sagsomkostninger i straffesager, bilag nr. 274 af 20. april 2012 fra Folketingets Retsudvalg til justitsministeren, s. 14). I Betænkning om sagsomkost- 
ninger i straffesager, Betænkning nr. 1547/2014 anbefaler udvalget bl.a. en såkaldt betalingsevnemodel, hvorudfra domfældte der i henhold til SKATs tabeltræksmodel ikke har en betalingsevne, ikke vil blive opkrævet pålagte sagsomkostninger, hvorimod domfældte der har en betalingsevne skal betale sagens udgifter til den beskikkede forsvarer (men ikke øvrige sagsomkostninger). De opkrævede udgifter vil blive fastsat efter et loft, som svarer til et beløb (udregnet på baggrund af oplysninger fra SKAT om den domfældtes forsørgerforpligtelse og nettoindkomst), som domfældte har mulighed for at afdrage på en kortere periode anslået til 2 år.

19. Se Kyvsgaard 1989, Nilsson 2002, Skardhamar 2002, Tranæs et al. 2008.

20. Jf. Skatteministeriet og notat fra Advokatrådets strafferetsudvalg vedrørende sagsomkostninger i straffesager, bilag nr. 274 af 20. april 2012 fra Folketingets Retsudvalg til justitsministeren, bilag 2 og 3 .

21. Retsfølelsen er ikke en klar og veldefineret størrelse, men en fælles betegnelse for nogle normative vurderinger der omhandler straf. Hvor retsfølelsen er svær at udlede empirisk og etisk har den derimod en tydelig retorisk funktion på den partipolitiske scene (Ryberg 2006: 15-19). Melchior problematiserer kløften mellem ret og følelse (Melchior 2008), og forskere der arbejder med retsfølelsen som begreb har da også udviklet forskellige definitioner til at favne denne udefinerbare normative størrelse. Balvig taler således om den generelle og den informerede retsfølelse. Den generelle retsfølelse er en betegnelse for »(...) de holdninger og følelser, man på det helt overordnede plan har til straf« hvor den informerede retsfølelse derimod kategoriserer »(...) de holdninger og følelser, man har til straf, når sagens grundlæggende karakter er kendt, og man systematisk er oplyst om de forskellige foreliggende sanktionsmuligheder (...) (Balvig 2006: 312-313).

22. Spørgsmålet henleder naturligvis til en diskussion om, hvorvidt retsfølelsen skal betragtes som et udtryk for viden eller vurdering, hvilket ikke er et emne, som denne artikel har til hensigt at behandle (se Ryberg 2006: 15-27, 49-50).

23. Balvig adskiller begrebet retsfølelse fra begrebet retsfornuft, hvor sidstnævnte ud fra en strafferetlig kontekst bliver defineret som »(...) den måde, man vil dømme på i konkrete sager, når man har tid til at overveje sagen, og er velinformeret om forbrydelsen, forbryderen, offeret og hvad eventuelle vidner har at sige« (Balvig 2010: 12). I denne artikel henviser retsfornuften til den måde, hvorpå velinformerede borgere anskuer uformel straf.

\section{Referencer}

Andenæs, J. (2009) Norsk straffeprosess. 4. utgave ved Tor-Geir Myhrer. Oslo: Universitetsforlaget.

Balvig, F. (2006) Danskernes syn på straf. Advokatsamfundet.

Balvig, F. (2010) Danskernes retsfølelse og retsfornuft - et forspil. Det Juridiske Fakultet, Københavns Universitet.

Bjerke, H.K., Keiserud, E. \& Sæther, K.E. (2011) Straffeprosessloven. Lov 22. mai 1981 nr. 25 om rettergangsmåten i straffesaker med senere endringer med kommentarer. 4 . utgave. Bind II. Oslo: Universitetsforlaget.

Christie, N. (2004): »Straffen som problem« i Nordisk tidsskrift for kriminalvidenskab. Vol. 91(4): 302-310. 
Ewick, P. \& Silbey, S.S. (1998): The Common Place of Law: Stories from Everyday Life. Chicago: University of Chicago Press.

Eyben, W.E. v. (1960) »Erstatningskrav i politisager og sagsomkostninger i politi- og andre straffesager« i Juristen, s. 217-227.

Gomard, B. (2013) Kommenteret retsplejelov. København: Jurist- og Økonomforbundets Forlag. Hindborg, L. (2006) Gceldssanering i praksis. København: Jurist- og Økonomforbundets Forlag. Jørgensen, M. (2004): »Sagens omkostninger« i Lov \& Ret. Vol. 14(2): 3-9.

Kaiser, J. (2012): »The Hidden Sentence: Rethinking 〉Offenders` Rights' and `Collateral Consequences« Punishment« paper presentation at The Law and Society Association, Honolulu, Hawaii (USA) 2012.

Kyvsgaard, B. (1989) ... og fangslet tager de sidste: om kriminalitet, straf og levevilkår. København: Jurist- og Økonomforbundets Forlag.

Lamaison, P. \& Bourdieu, P. (1986) »From Rules to Strategies: An Interview with Pierre Bourdieu« in Cultural Anthropology. Vol. 1(1): 110-120.

Larsen, O. (2009) Gaeld. København: Nyt Juridisk Forlag.

Melchior, T. (2008) »Retsfølelse - ret eller følelse?« i Danmarks domstole, nr. 43.

Merry, S.E. (1990) Getting Justice and Getting Even: Legal Consciousness among WorkingClass Americans. Chicago: University of Chicago Press.

Nautrup, J. (1984) »Sagsomkostninger i retssager« i Juristen. Vol. 66(3): 73-88.

Nautrup, J. (1995) »Sagsomkostningernes behandling under domsforhandlingen i straffesager $\mathrm{i}$ Fuldmagtigen. Vol. 67(5): 79-81.

Nilsson, A. (2002) Fånge i marginalen: uppväxtvillkor, levnedsförhållanden och återfall $i$ brott bland fängar. Stockholm: Stockholms Universitet.

Olesen, A. (2013a) »Eftergivelse af gæld vedrørende sagsomkostninger i straffesager« i Godsk Pedersen, H.V. (red.) Juridiske emner ved Syddansk Universitet 2013. Jurist- og Økonomforbundets Forlag, s. 327-344.

Olesen, A. (2013b) Løsladt og gaeldsat. København: Jurist- og Økonomforbundets Forlag.

Ryberg, J. (2006) Retsfølelsen. Frederiksberg: Roskilde Universitetsforlag.

Rørdam, B. (2010) »Håbløs gæld holder tidligere indsatte fanget« i Socialrådgiveren. Vol. 9: 23.

Rørdam, P. (1961) »Om tilståelsessager og om sagsomkostninger i straffesager « i Ugeskrift for retsvaesen, $\mathrm{s}$. 327-332.

Sarat, A. (1990): »The Law is All Over: Power, Resistance, and the Legal Consciousness of the Welfare Poor i Y Yale Journal of Law and the Humanities. Vol. 2: 343-379.

Skardhamar, T. (2002) Levekår og livssituasjon blant innsatte i norske fengsler. Oslo: Institutt for kriminologi og rettssosiologi.

Skjødt, B. (2004) »Sagens omkostninger og retssikkerheden« i Lov \& Ret. Vol. 14(3): 16-19.

Sørensen, D.A. \& Singh, M. (2010) Sagsomkostninger i straffesager. Det Juridiske Fakultet, Københavns Universitet.

Tranæs, T. et al. (2008) Forbryderen og samfundet. København: Gyldendal.

Travis, J. (2002): »Invisible Punishment: An Instrument of Social Exclusion« i Mauer M. \& Chesney-Lind M. (red.). Invisible Punishment: The Collateral Consequences of Mass Imprisonment. New York: The New Press, s. 15-36.

Travis, J. (2005): But They All Come Back. Washington, DC: Urban Institute Press. 
Travis J. \& Waul M. (eds.) (2003): Prisoners Once Removed: The Impact of Incarceration and Reentry on Children, Families, and Communities. Washington, DC: Urban Institute Press.

Wacquant, L.J.D. (1989) »Towards a Reflexive Sociology: A Workshop with Pierre Bourdieu« in Sociological Theory. Vol. 7(1): 26-63.

Werlauff, E. (1993) »Reglerne om sagsomkostninger er forældede« i Lov og Ret. Vol. 3(6).

Internetside:

http://www.domstol.dk/hojesteret/sagsbehandling/Pages/Slrtakster.aspx (lokaliseret d. 1. juli 2014) 